\title{
POLA PENERAPAN METODE CO-OP CO-OP DAN STRATEGI PENINJAUAN KEMBALI DALAM PEMBELAJARAN MATEMATIKA UNTUK MENINGKATKAN KEAKTIFAN DAN KREATIVITAS SISWA
}

\author{
Muhammad Istiqlal \\ IAIN Salatiga \\ $\underline{\text { m.istiqlal@iainsalatiga.ac.id }}$
}

\begin{abstract}
Abstrak
Keaktifan dan kreativitas siswa dalam pembelajaran matematika masing tergolong rendah. Terdapat banyak hal yang mempengaruhi rendahnya keaktifan dan kreativitas siswa. Salah satu yang menyebabkannya adalah pemilihan metode pembelajaran yang kurang tepat. Pemilihan metode pembelajaran harus didasarkan pada karakteristik materi dan karakteristik siswa. Pendekatan pembelajaran modern saat ini menuntut siswa untuk berusaha membangun sendiri pengetahuannya. Bantuan guru harus diminalisir agar siswa memiliki kebebasan untuk menemukan pengetahuannya sendiri. Dengan demikian siswa dapat terlibat aktif dalam pembelajaran, dan kreatif dalam menemukan solusi permasalahan matematika.

Kombinasi metode co-op dan strategi peninjauan kembali dimungkinkan untuk meningkatkan keaktifan dan kreativitas siswa. Penelitian ini menyimpulkan bahwa penerapan metode Co-op Co-op dan strategi peninjauan kembali pada pembelajaran matematika kelas VIII SMP Sunan Averroes Yogyakarta dapat meningkatkan aktivitas siswa. Dari hasil angket dapat diketahui bahwa terdapat adanya peningkatan aktivitas siswa dari siklus I ke siklus II yaitu sebesar 6,55\%. Penelitian ini menyimpulkan bahwa penerapan metode Co-op Co-op dan strategi peninjauan kembali pada pembelajaran matematika kelas VIII SMP Sunan Averroes Yogyakarta dapat meningkatkan kreativitas siswa. Dari hasil angket diketahui bahwa peningkatan kreativitas siswa dari siklus I ke siklus II yaitu sebesar 6,53 \%.
\end{abstract}

Kata Kunci: Metode Co-op co-op, strategi peninjauan kembali, keaktifan, kreativitas

\begin{abstract}
Activity and creativity of students in learning mathematics each classified as low. There are many things that affect the low activity and creativity of students. One of the causes is the selection of inappropriate learning methods. The selection of learning methods should be based on the topic and students characteristics. The modern learning approach requires students to try to build their own knowledge. Teacher help must be minimalized so that students have the freedom to find their own knowledge. Thus students can be actively involved in learning, and creative in finding solutions to mathematical problems.

The combination of co-op method and review strategy is possible to improve students' activity and creativity. This research concludes that the application of Co-op Co-op method and review strategy on 7th grade mathematics learning at SMP Sunan Averroes Yogyakarta can increase student activity. From the questionnaire results can be seen that there is an increase in student activity from cycle I to cycle II that is equal to $6.55 \%$. This research concludes that the
\end{abstract}


application of Co-op Co-op method and review strategy on 7th grade mathematics learning at SMP Sunan Averroes Yogyakarta can improve students' creativity. From the result of questionnaire, it is known that the improvement of student creativity from cycle I to cycle II is $6.53 \%$.

Keywords: Co-op co-op method, review strategy, activity, creativity

Sitasi: Istiqlal, M.. 2018. Pola Penerapan Metode Co-Op Co-Op dan Strategi Peninjauan Kembali dalam Pembelajaran Matematika untuk Meningkatkan Keaktifan Dan Kreativitas Siswa. Matematika dan Pembelajaran, 6(1), 70-90.

\section{PENDAHULUAN}

Dalam era globalisasi dan reformasi sekarang ini diperlukan adanya reorientasi pendidikan sebagai adaptasi terhadap perubahan-perubahan yang terjadi baik di Indonesia maupun di luar negeri (Munandar, 2004). Reorientasi pendidikan ini bertujuan agar pendidikan di Indonesia semakin maju dan berkembang.

Pendidikan menurut Kamus Besar Bahasa Indonesia ialah proses pengubahan sikap dan tata laku seseorang atau kelompok orang dalam usaha mendewasakan manusia melalui upaya pengajaran dan pelatihan. Dalam pengertian luas, pendidikan dapat diartikan sebagai sebuah proses dengan metode-metode tertentu sehingga orang memperoleh pengetahuan, pemahaman, dan bertingkah laku yang sesuai dengan kebutuhan (Syah, 2006).

Dari paparan tentang pendidikan diatas, dapat diambil kesimpulan bahwa pendidikan sangat penting dan wajib dilakukan oleh setiap orang. Pendidikan berusaha mengembangkan potensi individu agar mampu berdiri sendiri. Untuk itu, individu perlu diberi berbagai kemampuan dalam pengembangan berbagai hal, seperti : konsep, prinsip, kreativitas, tanggung jawab, dan keterampilan. Dengan kata lain manusia perlu mengalami perkembangan dalam aspek kognitif, afektif dan psikomotorik (Fattah, 2004) .

Melalui proses pendidikan, kita dapat mengembangkan aspek-aspek tersebut baik aspek kognitif, afektif dan psikomotorik. Aspek kognitif merupakan salah satu aspek atau kemampuan yang berhubungan dengan perkembangan fungsi intelektual atau proses perkembangan kemampuan/kecerdasan otak. Afektif merupakan kemampuan yang berhubungan dengan sikap dan sifat, sedangkan psikomotorik berhubungan dengan perolehan aneka ragam keterampilan fisik. Ketiga aspek tersebut sangat berpengaruh terhadap proses pembelajaran terutama dalam mengenal pribadi masing-masing individu.

Pembelajaran yang dilakukan pada masing-masing sekolah berbeda-beda tergantung pada kebijakan sekolah. Saat ini sekolah dan guru diberikan keleluasaan untuk mengembangkan kurikulum dan melaksanakan pembelajaran. Sejak terbit Permendiknas no 22, 23 dan 24 tahun 2006, kurikulum sekolah dikembangkan oleh masing-asing sekolah (KTSP). Guru berhak mengatur atau menyampaikan materi yang diajarkan sesuai dengan 
kebijakan guru dan masing-masing sekolah. Metode yang digunakan masing-masing guru pun berbeda-beda tergantung materi yang di sampaikan.

SMP Sunan Averroes, salah satu sekolah swasta yang terletak di Desa Sekarsuli, Kecamatan Berbah, Kabupaten Sleman saat ini juga telah mengembangkan sendiri kurikulum (KTSP) di Sekolah. Kurikulum di SMP Sunan Averroes ditujukan untuk menciptakan tamatan yang kompeten dan cerdas dalam mengemban identitas budaya dan bangsanya dan juga dapat memberikan dasar-dasar pengetahuan, keterampilan, pengalaman belajar yang membangun integritas sosial serta membudayakan dan mewujudkan karakter nasional.

Namun pada kenyataannya, KTSP yang dikembangkan di SMP Sunan Averroes ini belum dapat dilakukan secara optimal. Salah satu mata pelajaran yang ditemukan permasalahan dalam pelaksanaan KTSP adalah mata pelajaran matematika khususnya yang terjadi pada kelas VIII. Pembelajaran matematika di kelas ini belum berjalan secara optimal.

Berdasarkan hasil observasi selama separuh semester, beberapa masalah yang ditemukan diantaranya : siswa sering lupa terhadap materi yang diajarkan guru, metode yang digunakan guru dalam proses belajar mengajar cenderung monoton yaitu metode ceramah sehingga siswa mengalami kebosanan atau kurang antusias terhadap materi yang diajarkan, kurangnya kesadaran siswa untuk lebih rajin dan aktif dalam pembelajaran, siswa tidak mau maju ke depan kelas dengan kesadarannya sendiri melainkan setelah disuruh maju oleh guru, siswa ada yang bicara sendiri dan bermain sendiri saat guru menerangkan pelajaran/materi, akibatnya banyak siswa kurang paham terhadap materi yang diajarkan, kurangnya kreativitas dan daya intake/kemampuan siswa dalam proses belajar mengajar di kelas, kurangnya sarana prasarana yang dimiliki sekolah tersebut, misalnya tidak adanya laboratorium khusus matematika, kurangnya alat peraga matematika dan sebagainya.

Metode ceramah yang selama ini terlalu dominan menjadi salah satu penyebab siswa menjadi kurang aktif dan kurangnya kreativitas siswa dalam pembelajaran matematika. Oleh karena itu, guru dan peneliti bersepakat akan mencoba mencari solusi melalui pembaharuan metodologi mengajar yang diterapkan guru di kelas. Solusi ini penting agar pelaksanaan pembelajaran matematika dapat berjalan dengan lebih baik sehingga dapat memberikan hasil yang optimal.

Proses pembelajaran matematika di dalam kelas dapat berjalan secara efektif dan efisien jika siswa terlibat aktif dalam menemukan dan memahami konsep-konsep, strukturstruktur maupun rumus-rumus, karena belajar matematika itu memerlukan pemahaman konsep-konsep, di mana konsep-konsep ini akan melahirkan teorema atau rumus yang dapat diaplikasikan ke dalam situasi yang lain seperti dalam kehidupan sehari-hari.

Permasalahan-permasalahan yang dihadapi siswa khususnya siswa di kelas VIII SMP Sunan Averroes Sleman Yogyakarta dalam belajar matematika yaitu siswa sering 
lupa terhadap materi yang diajarkan guru, metode yang digunakan guru dalam proses belajar mengajar cenderung monoton, kurangnya kesadaran siswa untuk lebih rajin dan aktif dalam pemebelajaran, siswa ada yang bicara sendiri dan bermain sendiri saat guru menerangkan pelajaran/materi, kurangnya kreativitas dan daya intake/kemampuan siswa dalam proses belajar mengajar di kelas, dan kurangnya sarana prasarana yang dimiliki sekolah tersebut. Permasalahan-permasalahan tersebut harus segera ditindak lanjuti karena itu berpengaruh pada prestasi belajar siswa.

Pembelajaran Kooperatif dengan menggunakan metode Co-op Co-op dan strategi Peninjauan Kembali merupakan salah satu alternatif untuk menghadapi permasalahanpermasalahan di atas. Metode ini mengaharapkan siswa untuk lebih aktif dan lebih kreatif dalam proses belajar mengajar di kelas dan siswa bisa berkolaborasi dengan kelompoknya masing-masing untuk bertukar pikiran dan saling berbagi pemahaman baru sehingga mereka merasa senang, aktif, dan kreatif dalam pembelajaran.

Dari permasalahan-permasalahan yang telah di kemukakan di atas, peneliti mencoba menawarkan salah satu metode pembelajaran yang digunakan untuk mengurangi/mengatasi permasalahan yang ada, yaitu menggunakan metode Co-op Co-op. Co-op Co-op merupakan salah satu metode dalam model pembelajaran kooperatif. Metode ini menuntut semua siswa untuk aktif dan kreatif karena semua siswa dibagi menjadi beberapa kelompok dan masing-masing kelompok diberi tugas yang berbeda dengan kelompok lain kemudian tiap kelompok yang sudah selesai melaksanakan tugasnya disuruh mempresentasikan atau menampilkan penemuan mereka di hadapan seluruh kelas.

Peneliti juga menggunakan strategi Peninjauan Kembali yang akan dikolaborasikan dengan Metode Co-op Co-op. Strategi Peninjauan kembali ini hanya meninjau kembali pelajaran yang telah diajarkan. Strategi peninjauan kembali merupakan sebuah strategi yang akan membuat pembelajaran tetap melekat dalam pikiran yaitu dengan mengalokasikan waktu untuk meninjau kembali apa yang telah dipelajari. Strategi ini diharapkan dapat semakin mendorong siswa aktif dan meningkat pemahamnnya.

Perumusan masalah pada penelitian ini adalah 1) Bagaimanakah penerapan metode Co-op Co-op dan strategi peninjauan kembali pada pembelajaran matematika kelas VIII SMP Suna Averroes Sleman Yogyakarta dalam meningkatkan keaktifan siswa?; dan 2) Bagaimanakah penerapan metode Co-op Co-op dan strategi peninjauan kembali pada pembelajaran matematika kelas VIII SMP Sunan Averroes Sleman Yogyakarta dalam meningkatkan kreativitas siswa?

Winkel (2004) berpendapat bahwa belajar merupakan suatu aktivitas mental/psikis, yang berlangsung dalam interaksi aktif dengan lingkungan, yang menghasilkan sejumlah perubahan dalam pengetahuan-pemahaman, keterampilan dan nilai-sikap. Perubahan itu bersifat relatif konstan dan berbekas. Pendapat ini juga menitik beratkan pada perubahan, namun perubahan yang dimaksud lebih luas bukan hanya sekedar perubahan tingkah laku tetapi juga perubahan perubahan struktur kognitif seseorang. 
McGregor (2007: 60) menyampaikan pandangan kalangan sosio-kultural terhadap belajar, yaitu "learning is perceived as a gradual interactive process in which a novice engages as though in an apprenticeship". Belajar dipandang sebagai sebuah proses interaktif yang bertahap dimana seorang siswa dilibatkan dalam sebuah kegiatan magang. Kegiatan magang yang dimaksud adalah kegiatan yang membutuhkan partisipasi siswa secara bertahap. Race (2010) menyatakan bahwa "we can't really measure learning, but only evidence of achievement as a result of learning". Belajar sebenarnya tidak dapat diukur tetapi bukti prestasi merupakan sebuah hasil dari belajar.

Dari berbagai pendapat di atas, dapat disimpulkan bahwa belajar adalah proses yang dilakukan oleh seseorang melalui sebuah aktivitas mental/psikis untuk mendapatkan perubahan dalam dirinya baik perubahan tingkah laku maupun perubahan struktur kognitif. Selain itu belajar sebenarnya tidak dapat diukur, namun perkembangan yang diperlihatkan seseorang merupakan suatu hasil dari belajar.

Hergenhahn dan Olson (2008: 2) menyatakan bahwa belajar diukur berdasarkan perubahan dalam perilaku. Jadi hasil dari belajar tersebut direpresentasikan dalam perilaku. Selain itu Hergenhahn dan Olson (2008: 3) menambahkan empat poin lagi tentang belajar, yaitu (1) perubahan behavioral sebagai hasil dari belajar bersifat relative permanen, (2) perubahan perilaku tersebut itu tidak secara langsung setelah proses belajar selesai, (3) perubahan perilaku (atau potensi behavioral) berasal dari pengalaman atau praktik (latihan), dan (4) pengalaman, atau praktik, harus diperkuat; artinya hanya responsrespons yang menyebabkan penguatanlah yang akan dipelajari. Jadi, belajar adalah perubahan perilaku atau potensi perilaku yang relatif permanen yang berasal dari pengalaman dan tidak bisa dinisbahkan ke keadaan tubuh seperti keadaan yang disebabkan oleh sakit, keletihan atau obat-obatan.

Thorndike (Hergenhahn dan Olson, 2008: 61-62) menyimpulkan dua hal tentang belajar, yaitu (1) belajar bersifat incremental (bertahap) bukan insightful (langsung ke pengertian), dan (2) belajar adalah bersifat langsung dan tidak dimediasi oleh pemikiran atau penalaran. Joyce, et al (2004: 13) menambahkan bahwa "In the process of learning, the mind stores information, organizes it, and revises previous conceptions. Learning is not just a process of taking in new information, ideas, and skills, but the new material is reconstructed by the mind". Maksud pernyataan ini adalah bahwa dalam proses belajar, pikiran menyimpan informasi, mengatur, dan memperbaiki konsep-konsep sebelumnya. Belajar tidak hanya proses penyerapan informasi baru, gagasan, dan keterampilan, akan tetapi bagaimana mengkonstruksi kembali dari informasi materi baru yang diperoleh. Peristiwa belajar mengajar terjadi apabila subyek dididik secara aktif berinteraksi dengan lingkungan belajar yang diatur oleh guru.

Jadi, belajar memiliki beberapa komponen yang menjadi syarat bahwa sesuatu yang dilakukan itu merupakan bagian dari kegiatan belajar. Selain itu, belajar merupakan sesuatu yang sifatnya bertahap, artinya seseorang tidak bisa langsung mengetahui apa yang ingin diketahuinya, melainkan ada proses atau tahap yang mengantarkannya memperoleh apa yang menjadi tujuannya. Perubahan-perubahan yang terjadi akibat belajar bisa jadi 
tidak secara langsung diperoleh setelah kegiatan belajar selesai. Jadi, ada tahap perenungan terhadap apa yang sudah dipelajarinya kemudian direpresentasikan dalam perilaku maupun cara berpikir.

Nitko (2007) mengemukakan Instruction is the process you use to provide students with the conditions that help them achieve the learning targets. Some learning target are cognitive, meaning that they ideal primarily with intellectual knowledge and thinking skills. Other learning outcomes are affective, meaning that they ideal with how students should feel or what they should value. Yet other learning targets are psychomotor, meaning that they deal primarily with motor skills and physical preceptions. Pernyataan di atas dapat dipahami bahwa pembelajaran adalah proses yang digunakan guru untuk mengarahkan siswa dengan kondisi tertentu yang membantu mereka mencapai target belajar. Beberapa target belajar tersebut adalah 1) kognitif, yaitu berhubungan dengan pengetahuan intelektual dan ketrampilan berpikir, 2) afektif, yaitu berhubungan dengan bagaimana bisa merasakan dan apa yang seharusnya mereka nilai, dan 3) psikomotor, yaitu berhubungan dengan ketrampilan motorik dan tanggapan secara fisik.

Slavin (2006) menyatakan bahwa "effective instruction is not a simple matter of one person with more knowledge transmitting that knowledge to another". Pembelajaran yang efektif bukanlah masalah sederhana dimana seseorang dengan pengetahuan lebih mentransfer pengetahuan yang dimiliki tersebut kepada orang lain. Hal ini menunjukkan bahwa dalam pembelajaran dibutuhkan suatu perencanaan dan persiapan terhadap segala hal yang terkait dengan proses pembelajaran.

Brown (2000: 8) menjelaskan tentang pembelajaran bahwa pembelajaran tidak dapat dipisahkan dari proses belajar mengajar. Mengajar adalah membimbing dan memfasilitasi siswa yang belajar, mengatur kondisi untuk belajar, pemahaman terhadap bagaimana siswa belajar untuk menentukan filsafat pendidikan yang dipakai, gaya mengajar, pendekatan, metode, dan teknik yang digunakan dalam proses pembelajaran di kelas. Dick, et al, (2001: 2) menambahkan bawha inti pembelajaran adalah suatu proses yang sistematis di mana setiap komponen (yaitu, guru, pelajar, bahan, dan lingkungan belajar) sangat penting untuk keberhasilan pembelajaran.

Jadi pembelajaran adalah sutau proses interaksi antara guru dan siswa yang direncanakan dalam rangka memperoleh pengetahuan melalui berbagai metode yang dapat memanfaatkan segala sesuatu yang dapat dijadikan sebagai media untuk mencapai tujuan pembelajaran. Pembelajaran tidak dapat dilakukan secara tiba-tiba, melainkan harus direncakan terlebih dahulu sehingga proses mencapai tujuan pembelajaran dapat terlaksana secara sistematis dan terarah.

Permendiknas No. 22 Tahun 2006 tentang Standar Isi menyatakan bahwa tujuan pembelajaran matematika pada semua jenjang pendidikan dasar dan menengah adalah agar peserta didik: 1) emahami konsep matematika, menjelaskan keterkaitan antarkonsep dan mengaplikasikan kosep atau algoritma, secara luwes, akurat, efisien, dan tetap dalam pemecahan masalah, 2) menggunakan penalaran pada pola dan sifat, melakukan 
manipulasi matematikan dalam membuat generalisasi, menyusun bukti, atau menjelaskan gagasan dan pernyataan matematika; 3) memecahkan masalah yang meliputi kemampuan memahami masalah, merancang model matematika, menyelesaikan model, dan menafsirkan solusi yang diperoleh; 4) mengkomunikasikan gagasan dengan symbol, tabel, diagram, atau media lain untuk memperjelas keadaan atau masalah; dan 5)memiliki sikap menghargai kegunaan matematika dalam kehidupan, yaitu memiliki rasa ingin tahu, perhatian, dan minat dalam mempelajari matematika, serta sikap ulet dan percaya diri dalam pemecahan masalah. Secara umum, tujuan pembelajaran matematika di Indonesia menekankan pada pemecahan masalah matematika.

Sumardyono (2004: 33) menyebutkan empat obyek kajian matematika yaitu fakta, konsep, operas, dan prinsip. Fakta adalah pemufakatan atau konvensi dalam matematika yang biasanya diungkapkan lewat simbol tertentu. Konsep adalah ide abstrak yang dapat digunakan untuk menggolongkan atau mengkategorikan sekumpulan obyek, apakah obyek tertentu merupakan contoh konsep atau bukan. Operasi adalah pengerjaan hitung, pengerjaan aljabar atau pengerjaan matematika lainnya, sementara relasi adalah hubungan antara dua atau lebih elemen. Prinsip adalah obyek matematika yang lengkap, yang terdiri atas beberapa konsep, beberapa fakta yang dikaitkan oleh suatu relasi ataupun operasi.

Lebih lanjut Sumardyono (2004: 12) menyatakan bahwa obyek-obyek matematika bersifat sosial-kultural-historis, artinya bahwa matematika dan pembelajarannya merupakan milik bersama seluruh umat. Betapapun primitifnya suatu masyarakat, matematika adalah bagian dari kebudayaannya (meski dalam bentuk yang sederhana). Karena itu matematika bersifat universal. Matematika itu sendiri lahir dari perjalanan panjang yang menyejarah dalam kehidupan manusia.

Beberapa definisi atau ungkapan matematika hanya dikemukakan dengan maksud agar pembaca dapat menangkap dengan mudah keseluruhan pandangan para ahli matematika. Tokoh yang sangat tertarik perilaku bilangan, melihat matematika dari sudut pandang bilangan. Tokoh lain lebih perhatian pada struktur, melihat matematika dari struktur. Tokoh lain lagi lebih tertarik pola pikir atau sistematika, kemudian melihat matematika dari sistematika matematika itu. Akhirnya, muncul definisi atau pengertian matematika beraneka ragam, sehingga berdampak tidak adanya definisi matematika yang tunggal dan disepakati semua tokoh atau pakar matematika.

Pembelajaran matematika adalah suatu aktifitas yang disengaja untuk memodifikasi berbagai kondisi yang diarahkan untuk tercapai tujuan melalui kegiatan penalaran sehingga objek matematika yang abstrak dan bersifat sosio-kulturalis dapat tersampaikan dan tujuan pembelajaran matematika dapat tercapai (Sumardyono, 2004: 12). Jadi sebelum melakukan pembelajaran matematika, harus ditentukan terlebih dahulu tujuannya, supaya kegiatan penalaran yang terjadi dalam kegiatan pembelajaran menjadi terarah.

Dari pemaparan di atas, pembelajaran matematika sekolah merupakan suatu kegiatan pembelajaran yan direncanakan untuk mencapai tujuan pembelajaran matematika di sekolah. Pembelajaran matematika sekolah mimiliki enam prinsip, yaitu keadilan, 
kurikulum, pengajaran, belajar, penilaian, dan teknologi. Obyek kajian matematika sekolah, diantaranya fakta, konsep, prinsip, operasi, dan prinsip. Obyek-obyek kajian tersebut termuat dalam materi matematika yang dikelompokkan ke dalam tiga kelompok besar, yaitu aljabar, analisis, dan geometri.

Metode Co-op Co-op merupakan salah satu metode dari pembelajaran Kooperatif. Metode ini menempatkan tim dalam kooperasi antara satu dengan yang lainnya (seperti namanya) untuk mempelajari sebuah topik di kelas.(Slavin, 2006). Co-op Co-op memberi kesempatan pada siswa untuk bekerja sama dalam kelompok-kelompok kecil, pertama untuk meningkatkan pemahaman mereka tentang diri mereka dan dunia, dan selanjutnya memberikan mereka kesempatan untuk saling berbagi pemahaman baru itu dengan temanteman sekelasnya. Metodenya sederhana dan fleksibel. Begitu guru bisa memegang filosofi Co-op Co-op, maka mereka bisa memilih sekian macam cara untuk mengaplikasikan metode ini dalam kelas. Walaupun demikian, bila mengikuti sembilan langkah spesifik meningkatkan kemungkinan sukses dari metode ini.(Slavin, 2006)

Langkah ke-1: yaitu diskusi Kelas Terpusat pada siswa. Pada awal memulai pelajaran di kelas dimana Co-op Co-op digunakan, siswa di dorong untuk menemukan dan mengekspresikan ketertarikan mereka sendiri terhadap materi yang akan dipelajari. Kemudian biarkan siswa untuk melakukan diskusi, diskusi yang dilakukan adalah diskusi yang terpusat pada siswa. Diskusi harus mengarah pada sebuah pemahaman diantara guru dan semua siswa mengenai apa yang ingin dipelajari dan dialami oleh para siswa sehubungan dengan topik yang akan dicakupi.

Langkah ke-2: Menyeleksi Tim pembelajaran siswa dan Pembentukan Tim. Apabila para siswa belum mulai bekerja dalam tim, aturlah mereka ke dalam tim heterogen yang terdiri dari empat sampai lima anggota seperti dalam STAD. Para siswa perlu memiliki kelompok kerja dengan kemampuan yang baik dan kepercayaan yang terbangun sebelum memulai Co-op Co-op.

Langkah ke-3 : Seleksi Topik tim. Masing-masing tim memilih topik sesuai topik yang telah ditentukan oleh guru. Kemudian mendorong para siswa untuk mendiskusikan berbagai macam topik yang telah mereka pilih.

Langkah ke-4 : Pemilihan Topik Kecil. Begitu kelas sebagai sebuah keseluruhan membagi unit pelajaran ke dalam bagian-bagian untuk menciptakan pembagian tugas di antara tim-tim yang ada di kelas, tiap tim membagi topiknya untuk membuat pembagian tugas di antara anggota tim. Tiap siswa memilih topik kecil yang mencakup satu aspek dari topik tim.

Langkah ke-5 : Persiapan Topik Kecil. Setelah para siswa membagi topik tim mereka menjadi topik-topik kecil, mereka akan bekerja secara individual. Mereka masing-masing tahu akan tanggung jawabnya terhadap topik kecil mereka dan bahwa kelompok tersebut tergantung pada mereka untuk menemukan aspek penting dari usaha yang dilakukan tim. 
Langkah ke-6 : Persentasi Topik Kecil. Setelah para siswa menyelesaikan kerja individual mereka, mereka mempresentasikan topik kecil mereka kepada teman satu timnya. Selama presentasi topik kecil, pembagian tugas di dalam bisa didorong supaya ada satu anggota tim yang mencatat, yang lainnya mengkritik, yang lain lagi memberi dukungan, dan yang lain lagi memeriksa poin-poin yang mencapai titik temu dan yang tidak dari informasi yang dipresentasikan.

Langkah ke-7 : Persiapan Presentasi Tim. Para siswa didorong untuk memadukan semua topik kecil dalam presentasi tim. Di sana harus ada sintesis aktif dari topik keciltopik kecil tersebut supaya selama diskusi tim presentasi tim akan menjadi lebih dari sekadar sekumpulan presentasi topik kecil.

Langkah ke-8 : Presentasi Tim. Selama waktu presentasinya, tim memegang kendali kelas. Semua anggota tim bertanggung jawab pada bagaimana waktu, ruang, dan bahanbahan yang ada di kelas digunakan dalam presentasi mereka; mereka sangat dianjurkan untuk menggunakan sepenuhnya fasilitas-fasilitas yang ada di kelas. Dalam presentasi mereka tim boleh saja memasukkan sebuah periode tanya-jawab dan/waktu untuk memberikan komentar dan umpan balik.

Langkah ke-9 : Evaluasi. Evaluasi ini dilakukan pada tiga tingkatan : (1) pada saat presentasi tim dievaluasi oleh kelas; (2) kontribusi individual terhadap usaha tim dievaluasi oleh teman satu tim; dan (3) pengulangan kembali materi atau presentasi topik kecil oleh tiap siswa dievaluasi oleh sesama siswa.

Salah satu cara yang pasti untuk membuat pembelajaran tetap melekat dalam pikiran adalah dengan mengalokasikan waktu untuk meninjau kembali apa yang telah dipelajari. Materi yang telah di bahas oleh siswa cenderung lima kali lebih melekat di dalam pikiran ketimbang materi yang tidak. Itu karena pembahasan kembali memungkinkan siswa untuk memikirkan kembali informasi tersebut dan menemukan cara untuk menyimpanny di dalam otak. (Silbernan, 2006: 249)

Selain menjadi aktif, strategi ini menjadikan peninjauan kembali sebagai aktivitas yang menyenangkan. Diantara strategi tersebut antara lain (Silbernan, 2006: 249-267) pencocokkan kartu indeks, peninjauan ulang topik, bowling campus, memberikan pertanyaan dan mendapatkan jawaban, teka-teki silang, meninjau kesulitan pada materi pelajaran, ikhtisar siswa, tinjauan ala permainan bingo, dan tinjauan ala permainan "Hollywood Squares"

Aktif menurut Kamus Bahasa Indonesia diartikan sebagai giat, rajin, gigih (bekerja dan berusaha). Aktif berarti selalu berusaha, bekerja, atau belajar dengan sungguh-sungguh supaya mendapat kemajuan atau prestasi yang gemilang, sedangkan keaktifan diartikan sebagai aktivitas, kegiatan, kesibukan. (Salim dkk, 1991) Dengan demikian keaktifan siswa diartikan sebagai keadaan di mana siswa dapat aktif dengan suatu kegiatan/kesibukan. Dalam pembelajaran, siswa harus bersikap aktif sesuai dengan perannya sebagai subyek pembelajaran. 
Pembelajaran aktif dkenal pula dengan istilah Cara Belajar Siswa aktif (CBSA) atau Student Active Learning (SAL). Siswa yang lebih berpartisipasi aktif dalam pembelajaran sedemikian sehingga kegiatan siswa dalam belajar jauh lebih dominan pada kegiatan guru mengajar. (Salim dkk, 1991) Pembelajaran aktif penekanannya adalah bagaimana siswa mengkonstruksikan pemahamannya tentang sesuatu yang dipelajarinya.

Pembelajaran aktif lebih banyak ditinjau dari sisi siswa daripada guru. Siswa lebih berpartisipasi aktif sedemikian sehingga kegiatan siswa dalam belajar jauh lebih dominan dari pada kegiatan guru dalam mengajar. (Mohammad Ali, 1983: 6) Siswa dapat mengkonstruksi sendiri pengetahuan yang dipelajari, tidak hanya duduk diam mendengarkan penjelasan guru saja.

Dari uraian diatas, pada akhirnya dapat disimpulkan bahwa strategi belajar mengajar CBSA memiliki perbedaan - perbedaan jika dibandingkan dengan strategi lain yang bersifat tradisional yaitu :

Tabel 1 .

Perbedaan cara lama dan cara belajar siswa aktif

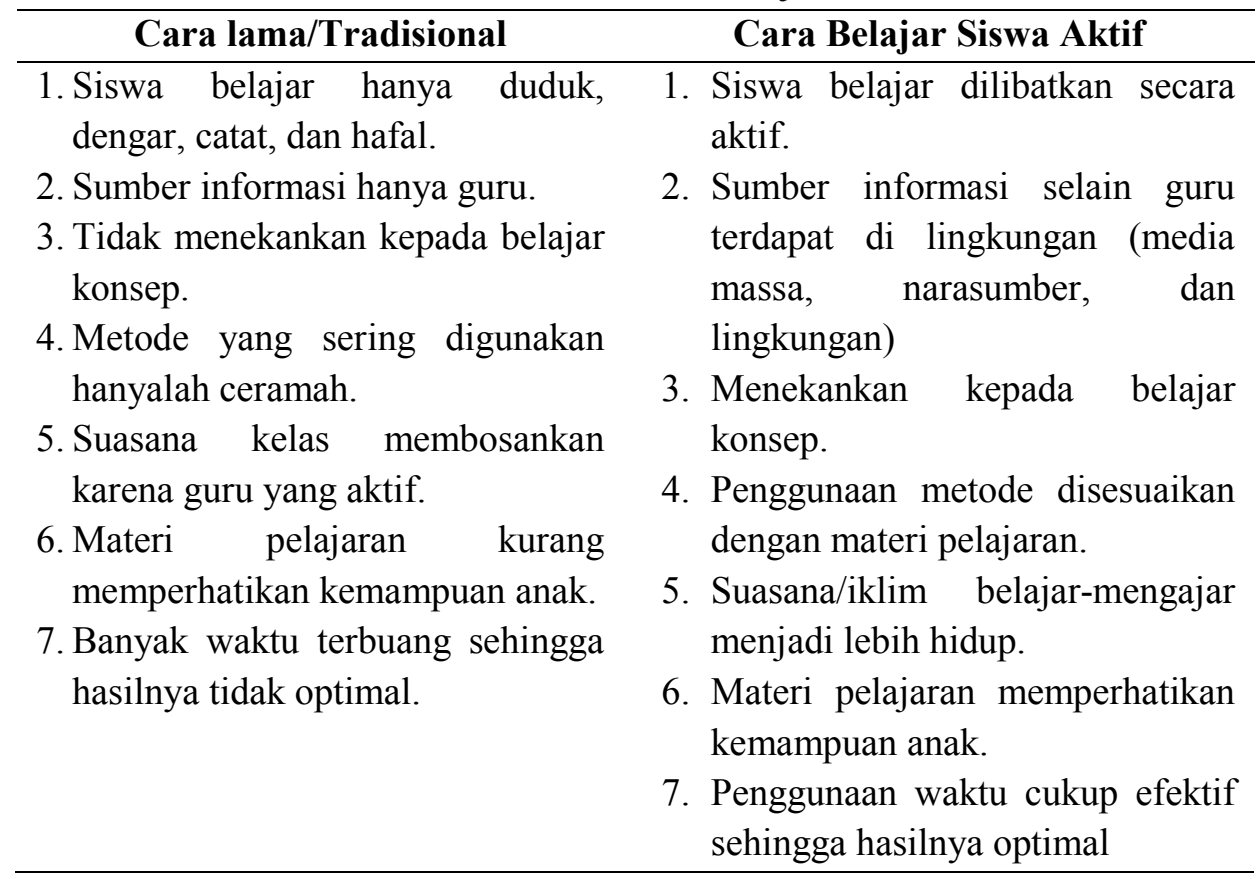

Kata kreativitas berasal dari kata Inggris creativity, yang berarti daya cipta. Mengenai definisi kreativitas terdapat berbagai macam, tergantung bagaimana dan dari segi mana orang melihatnya.(Sutrisno, 2005). Menurut kamus besar bahasa Indonesia, kreativitas mempunyai arti kemampuan untuk mencipta atau perihal kreasi. Kreativitas berawal dari kata kreatif yang artinya mempunyai kemampuan mencipta atau mengandung daya cipta(Depdikbud, 1988). Amin (1980) mendefinisikan kreatif sebagai pola pikir atau ide yang timbul secara spontan dan imajinatif yang menciptakan hasil artistik, penemuan ilmiah dan penciptaan mekanis. 
Kreativitas juga diartikan sebagai kemampuan untuk membuat kombinasi baru berdasarkan data, informasi, atau unsur-unsur yang ada. Dalam hal ini sesungguhnya apa yang diciptakan itu tidak perlu hal-hal yang baru sama sekali, tetapi merupakan gabungan (kombinasi) dari hal-hal yang sudah ada sebelumya.( Munandar, 2004) Jadi, secara operasional kreativitas dapat dirumuskan sebagai kemampuan yang mencerminkan kelancaran, keluwesan (fleksibilitas), dan orginalitas dalam berpikir serta kemampuan untuk mengelaborasi (mengembangkan, memperkaya, memperinci) suatu gagasan.

Beberapa penelitian juga menunjukkan bahwa keaktifan dan kreativitas siswa dapat ditingkatkan memlalui pendekatan kooperatif. Penelitian yang pertama dilakukan oleh Novilia Sri Retno Purwaningtyas (2004) telah meneliti tentang “ Usaha meningkatkan Keaktifan Siswa dalam pembelajaran matematika melalui kegiatan kelompok “ . Kesimpulan dari penelitiannya yaitu metode tersebut dapat meningkatkan keaktifan siswa, keaktifannya meliputi bertanya kepada guru, menjawab pertnyaan guru atas inisiatif sendiri, berdiskusi, mengerjakan LKS, mengerjakan PR, dan membuat alat peraga.

Penelitian yang kedua dilakukan oleh Fatimatuz Zahro (2006) meneliti tentang "Upaya meningkatkan kreativitas dan efektifitas dalam pembelajaran matematika melalui Pendekatan Accelerated learning pada siswa kelas IV di Madrasah Mualimat Muhammadiyah Yogyakarta". Dari hasil data yang didapat yaitu adanya peningkatan kompetensi siswa yang terlihat pada pencapaian hasil belajar, keaktifan siswa selama proses pembelajaran dan terwujudnya proses pembelajaran yang menyenangkan, maka dapat disimpulkan bahwa dengan melalui pendekatan accelerated learning dapat meningkatkan efektifitas dalam pembelajaran matematika.

\section{METODE}

Penelitian ini merupakan Penelitian Tindakan Kelas (PTK) atau disebut juga Classroom Action Research (CAR). Secara ringkas, penelitian tindakan kelas adalah bagaimana guru dapat mengorganisasikan kondisi praktek pembelajaran mereka, dan belajar dari pengalaman mereka sendiri. Mereka dapat mencobakan sesuatu gagasan perbaikan dalam praktek pembelajaran mereka, dan melihat pengaruh nyata dari upaya itu.

Pendekatan yang dilakukan dalam penelitian ini adalah penelitian kualitatif. Pendekatan penelitian kualitatif adalah pendekatan penelitian yang berlandaskan pada filsafat postpositivisme, digunakan untuk meneliti pada kondisi obyek yang alamiah, (sebagai lawannya adalah eksperimen) dimana peneliti adalah sebagai instrumen kunci, pengambilan sampel sumber data dilakukan secara purposive dan snowbal, teknik pengumpulan dengan trianggulasi (gabungan), analisis data bersifat induktif/kualitatif, dan hasil penelitian kualitatif lebih menekankan makna daripada generalisasi. (Sugiyono. 2007)

Penelitian dengan pendekatan kualitatif lebih menekankan analisisnya pada proses penyimpulan deduktif dan induktif serta pada analisis terhadap dinamika hubungan antar fenomena yang diamati, dengan menggunakan logika ilmiah. Hal ini bukan berarti bahwa 
pendekatan kualitatif sama sekali tidak menggunakan dukungan data kuantitatif akan tetapi penekanannya tidak pada pengujian hipotesis melainkan usaha menjawab pertanyaan penelitian melalui cara-cara berfikir formal dan argumentatif.(Saifuddin Azwar, 1998: 5).

Penelitian dilaksanakan di SMP Sunan Averroes. Subyek penelitian ini adalah siswa kelas VIII SMP Sunan Averroes yang berjumlah 20 siswa. Adapun obyek penelitian ini adalah pelaksanaan pembelajaran matematika dengan menggunakan metode Co-op Co-op dan Strategi Peninjauan Kembali.

Penelitian tindakan kelas dapat dilaksanakan melalui empat tahap utama yaitu perencanaan, tindakan, observasi dan refleksi. Empat langkah utama yang saling berkaitan itu dalam penelitian tindakan kelas sering disebut dengan istilah satu siklus

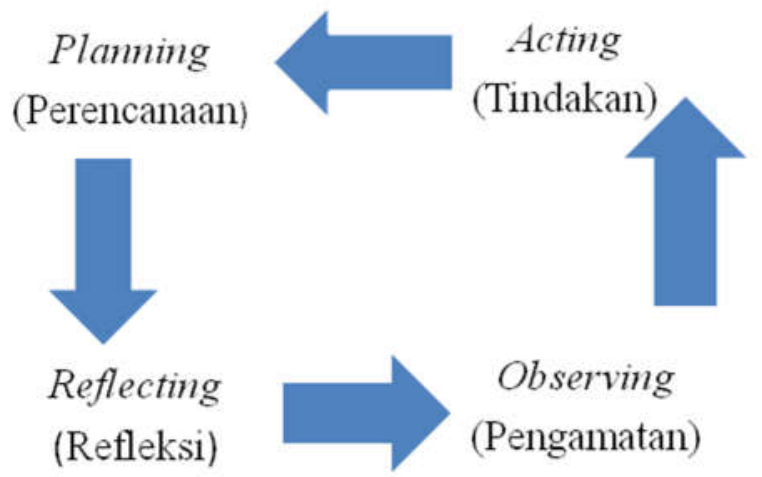

\section{Gambar 1: Tahapan (siklus) dalam PTK}

Keempat tahap dalam penelitian tindakan tersebut adalah unsur yang membentuk sebuah siklus, yaitu satu putaran kegiatan beruntun, yang kembali ke langkah semula. Apabila sudah diketahui letak keberhasilan dan hambatan dari tindakan yang baru selesai dilaksanakan dalam satu siklus, guru pelaksana bersama peneliti pengamat menentukan rancangan untuk siklus kedua. Jika sudah selesai dengan siklus kedua dan guru bersama peneliti belum merasa puas, dapat melanjutkan ke siklus ketiga, yang cara dan tahapannya sama dengan siklus sebelumnya.(Suharsimi Arikunto, 2007: 21). Apabila dalam siklus kedua letak keberhasilan sudah telihat yaitu dengan dibuktikannya meningkatnya keaktifan dan kreativitas siswa maka siklus akan dihentikan pada siklus yang kedua.

Teknik pengumpulan data dalam penelitian ini dilakukan dengan interview (wawancara), kuesioner (angket), dan observasi (pengamatan). Teknik analisis data yang digunakan dalam penelitian ini menggunakan analisis data kualitatif. Analisis data dalam penelitian kualitatif dilakukan sejak sebelum memasuki lapangan, selama di lapangan, dan setelah selesai di lapangan. Dalam penelitian kualitatif analisis data lebih difokuskan selama proses di lapangan bersamaan pengumpulan data.

Analisis data dalam penelitian kualitatif, dilakukan pada saat pengumpulan data berlangsung, dan setelah selesai pengumpulan data dalam periode tertentu. Data yang 
diperoleh dalam penelitian ini berupa data hasil observasi tentang proses pembelajaran, catatan lapangan selama proses pembelajaran, data hasil belajar siswa, dan hasil pengisisan angket siswa dan guru. Data yang tidak terstruktur yaitu dokumentasi (foto) dan hasil wawancara dengan siswa.

Indikator keberhasilan penelitian merupakan sesuatu yang digunakan sebagai ukuran berhasil tidaknya suatu penelitian yang dilakukan. Komponen-komponen yang menjadi indikator keberhasilan dalam penelitian ini adalah sebagai berikut: 1) Siswa dianggap lebih aktif apabila siswa lebih berani bertanya, mengemukakan pendapat, mempertanyakan gagasan orang lain, merespon apa yang disampaikan guru dan berani mempresentasikan hasil diskusinya ke depan kelas; 2) Siswa dianggap lebih kreatif apabila siswa lebih mampu menyelesaikannya dengan cara mereka sendiri yang dapat dipertanggungjawabkan, mampu mengoreksi suatu jawaban benar atau salah, dan siswa mencari-cari soal dari buku lain dan mencoba menyelesaikan sendiri.

\section{HASIL PENELITIAN DAN PEMBAHASAN}

\section{Pola Penerapan Metode Co-op co-op Menggunakan Strategi Peninjauan Kembali}

Co-op Co-op merupakan salah satu metode dari pembelajaran Kooperatif. Metode ini menempatkan tim dalam kooperasi antara satu dengan yang lainnya (seperti namanya) untuk mempelajari sebuah topik di kelas. Langkah-langkahnya yaitu :

Diskusi Kelas Terpusat pada siswa. Pada saat pembelajaran dimulai, guru mendorong dan memberi tahu kepada siswa bahwa metode pembelajaran pada pertemuan ini adalah pembelajaran yang berpusat pada siswa, pembelajaran ini dilakukan dalam bentuk kelompok-kelompok dan penyelesaian soal dilaksanakan dengan diskusi. Dari sini siswa bisa muncul aktivitas dan kreativitasnya karena siswa disuruh berkelompok untuk menyelesaikan suatu permasalahan. Aktivitas muncul pada saat siswa berkelompok mereka aktif bertanya kepada temannya ketika mereka mengalami kesulitan dalam mengerjakan soal, mereka juga saling berinteraksi dan bertukar pikiran dengan teman sekelompoknya. Sedangkan kreativitas mereka muncul saat mereka mengerjakan soal yang diberikan, saat soal diberikan mereka mengerjakannya dengan berbagai cara yang mereka anggap mudah, munculnya gagasan-gagasan baru, dan munculnya berbagai macam pertanyaan.

Menyeleksi Tim pembelajaran siswa dan Pembentukan Tim. Guru membagi siswa menjadi 4 kelompok yang masing-masing kelompok terdiri dari 5-6 siswa. Pembagian kelompok tersebut dipilih secara heterogen agar dalam berdiskusi siswa yang sudah bisa mau mengajarkan kepada siswa yang belum bisa dan mereka bisa berdiskusi dengan sebaik mungkin dalam menyelesaikan suatu persoalan dan mereka dapat bekerjasama dalam menyelesaikan suatu persoalan.

Seleksi Topik tim. Guru telah membagi materi menjadi beberapa sub materi. Dalam hal ini, guru menggunakan materi SPLDV dalam penelitian ini. Guru menggunakan LKS untuk mempermudah dalam pembagian materi tersebut. Pada siklus I, materi yang 
digunakan adalah menyelesaikan SPLDV menggunakan metode grafik. Pada siklus II guru akan memberikan dua buah materi, yaitu menyelesaikan SPLDV menggunakan metode eliminasi dan campuran, serta soal dalam LKS dibuat berbeda-beda dengan yang lain, dari sini siswa bisa terlihat kreativitasnya baik pada saat mengerjakannya maupun tentang kesukaannya terhadap soal yang sulit atau yang mudah. Pada saat mengerjakan mereka bisa menguraikan jawaban secara terperinci, dan mereka juga bisa bertanya ketika mereka mengalami kesulitan.

Pemilihan Topik Kecil. Guru membagi LKS yang berisi soal kepada siswa. Masingmasing siswa dalam satu kelompok mendapatkan soal yang berbeda-beda, sehingga mereka harus membagi tugas untuk mengerjakan LKS atau soal yang didapatkan. Pada saat pemilihan topik kecil ini diharapkan mereka bisa memilih soal sesuai yang mereka senangi sehingga mereka dapat menjawabnya. Pada saat mengerjakan LKS, siswa bisa lebih aktif baik dalam bertanya maupun menjawab pertanyaan dan juga siswa lebih kreatif dalam menemukan pemecahannya dengan caranya sendiri dan bisa mengerjakan soalnya dengan terperinci.

Persiapan Topik Kecil. Mereka mengerjakan LKS yang diberikan oleh guru secara individu dan mereka bertanggung jawab terhadap hasil pekerjaannya. Guru menyuruh siswa untuk mempersiapkan topik kecil mereka untuk mereka presentasikan kepada teman satu kelompoknya.

Persentasi Topik Kecil. Setelah para siswa menyelesaikan kerja individual mereka, mereka mempresentasikan topik kecil atau hasil pekerjaan mereka kepada teman satu timnya. Dari sini terlihat aktivitasnya yaitu mampu mempresentasikan hasil kerja individu. Siswa yang asalnya tidak mau atau malu untuk presentasi, mereka akan dilatih untuk mampu mempresentasikan hasil kerja individu. Dan dalam presentasi topik kecil ini juga muncul kreativitasnya yaitu mereka dapat menanggapi pertanyaan yang diajukan oleh teman sekelompoknya.

Persiapan Presentasi Tim. Para siswa didorong untuk memadukan semua topik kecil dalam presentasi tim. Mereka memadukan hasil pekerjaan mereka dalam satu kelompok. Dari sini terlihat adanya interaksi antara siswa yang satu dengan yang lainnya. Kemudian guru memberikan sebuah soal kepada masing-masing kelompok untuk mereka presentasikan di depan kelas.

Presentasi Tim. Setelah mereka mengerjakan soal kelompok mereka, mereka mempresentasikan hasil kerja kelompoknya kepada teman-temannya. Dari sini nampak aktivitasnya yaitu mampu mempresentasikan hasil kerja secara kelompok. Dan dalam pekerjaannya itu juga nampak kreativitasnya yaitu mereka mampu menguraikan jawabannya secara terperinci. Dalam presentasi tesebut muncul berbagai macam pertanyaan dan gagasan dari siswa lain, dan kelompok yang presentasipun dapat menanggapi pertanyaan yang diajukan. 
Evaluasi. Dalam evaluasi ini hanya dilihat dari aktivitas siswa dan kreativitas siswa dalam mengerjakan LKS. Aktivitasya dilihat ketika presentasi di depan kelompoknya maupun presentasi di depan kelas yaitu mereka mampu mempresentasikan hasil kerja baik individu maupun kelompok, berpartisipasi aktif dalam kegiatan kelompok. Kreativitasnya juga dapat dilihat dari hasil pekerjaannya, banyaknya gagasan dan pertanyaan yang ditimbulkan.

Setelah metode Co-op co-op diterapkan kemudian dilanjutkan dengan penerapan strategi peninjauan kembali. Dalam hal ini, guru hanya memberikan soal-soal kepada siswa yang digunakan untuk meninjau kembali materi atau soal yang mereka belum fahami. Apabila sudah faham, maka guru akan melanjutkan materi, tetapi apabila belum faham, maka guru akan mengulang materi yang telah diajarkan. Dalam strategi peninjauan kembali ini, peneliti menggunakan beberapa strategi dalam penelitiannya yaitu bowling kampus dan pencocokkan kartu indeks. Dalam pencocokkan kartu indeks, siswa akan lebih aktif karena siswa yang dapat pertanyaan akan mencari jawabannya ketemannya, begitu juga sebaliknya. Dalam bowling kampus, siswa juga tambah aktivitas dan kreativitasnya karena dalam strategi ini, guru memberikan beberapa pertanyaan kepada siswa dan masing-masing siswa berlomba-lomba dan bersaing untuk berebut menjawabnya.

\section{Aktivitas siswa}

Aktivitas siswa diartikan sebagai keadaan di mana siswa dapat aktif dengan suatu kegiatan/kesibukan. Dalam penelitian menggunakan metode co-op co-op dan strategi peninjauan kembali di SMP Sunan Averroes ini, data tentang aktivitas siswa dilihat dari 5 indikator aktivitas, yaitu bertanya baik kepada guru maupun temannya apabila mengalami kesulitan, menjawab pertanyaan dari guru, mengerjakan soal-soal dengan diskusi sehingga menambah interaksi dengan temannya, mempresentasikan hasil kerja baik individu maupun kelompok, dan berpartisipasi aktif dengan kelompok dalam penyelesaian permasalahan.

Data aktivitas siswa dalam penelitian ini diperoleh dari lembar observasi aktivitas, hasil wawancara dan hasil pengisian angket. Dari lembar observasi aktivitas, dari siklus pertama hingga siklus kedua aktivitas siswa mengalami peningkatan. Aktivitas terjadi saat metode co-op co-op dan strategi peninjauan kembali diterapkan. Langkah pertama pada metode co-op co-op yaitu diskusi kelas terpusat pada siswa, disini aktivitas siswa mulai terlihat karena siswa yang aktif dalam pembelajaran, sedangkan guru hanya sebagai fasilitator saja. Siswa di tuntut untuk melakukan diskusi dengan teman-temannya mengenai materi yang diajarkan. Pada siklus pertama, diskusi yang dilakukan belum maksimal karena siswa masih bingung dengan metode yang diterapkan. Kemudian setelah dilakukan beberapa siklus baru diskusi ini bisa berjalan dengan baik. Langkah yang kedua yaitu menyeleksi tim dan pembentukan tim/kelompok. Pada langkah kedua ini, aktivitas siswa muncul ketika mereka telah berkumpul dengan kelompoknya, mereka saling berinteraksi antara satu dengan yang lain. Mereka berpartisipasi aktif dalam kegiatan kelompok. 
Pada siklus I dan II siswa dibagi menjadi 4 kelompok yang terdiri dari 5-6 siswa yang heterogen. Langkah yang kedua yaitu seleksi topik tim. Tiap-tiap kelompok memilih topik/materi yang mereka senangi untuk mereka kerjakan. Guru menggunakan LKS untuk mempermudah dalam pembagian materi. Dari masing-masing kelompok bisa aktif dalam mengerjakan soal yang dipilih. Langkah yang keempat yaitu pemilihan topik kecil. Masingmasing siswa dalam kelompok memilih soal yang disenangi, dari sini muncul aktivitas siswa yaitu mereka aktif dalam memilih soal yang mereka kehendaki. Langkah yang kelima yaitu persiapan topik kecil. Masing-masing siswa aktif dalam mempersiapkan jawaban dari soal yang mereka kerjakan. Pada siklus I, siswa kurang begitu siap dalam mempersiapkannya, akibatnya ada beberapa siswa yang tidak mempresentasikan hasilnya, tapi setelah dilakukan beberapa tindakan siswa sudah siap dalam mempersiapkannya. Langkah yang keenam yaitu presentasi topik kecil. Dari sini aktivitas siswa bisa muncul yaitu mampu mempresentasikan hasil kerja individu kepada teman sekelompoknya. Pada siklus I, sebagian besar siswa tidak mau untuk mempresentasikan hasil kerjanya karena mereka masih malu dan takut salah. Pada siklus II, masing-masing siswa sudah mampu untuk mempresentasikan hasil kerjanya kepada kelompoknya.

Langkah selanjutnya yaitu persiapan presentasi tim. Pada langkah ini masingmasing kelompok mengerjakan soal yang diberikan guru, mereka mengerjakan secara kelompok, sehingga aktivitas yang muncul adalah mereka bisa berpartisipasi aktif dalam kegiatan kelompok. Setelah mempersiapkan presentasi tim, langkah selanjutnya yaitu presentasi tim. Pada presentasi tim ini aktivitas yang terjadi yaitu mampu mempresentasikan hasil kerja secara kelompok. Pada siklus I, mereka masih malu dalam mempresentasikan hasil kerja kelompok bahkan ada yang tidak mau untuk mempresentasikannya. Pada siklus II, sebagian besar siswa sudah mampu untuk mempresentasikan hasil kerja kelompoknya. Setelah presentasi tim dilanjutkan dengan tanya jawab. Pada siklus pertama, siswa masih malu-malu ketika akan bertanya kepada teman-temanya, mereka cenderung bertanya langsung kepada guru. Dalam menjawab pertanyaan yang diberikan guru, mereka masih malu-malu atau kadang-kadang memilih diam daripada menjawab pertanyaan yang diberikan guru. Pada siklus kedua siswa sudah terlihat aktif dalam bertanya maupun menjawab pertanyaan yang diberikan guru. Dalam bertanya, para siswa sudah mau bertanya baik kepada guru maupun kepada temannya apabila mereka merasa kesulitan dalam menjawab pertanyaan. Apabila guru memberikan pertanyaan, mereka juga menjawab apabila mereka mampu menjawabnya.

Setelah penerapan metode co-op co-op dilanjutkan dengan strategi peninjauan kembali. Dengan adanya penerapan strategi ini, aktivitas siswa bisa muncul ketika guru memberikan pertanyaan yaitu mereka aktif dalam menjawab pertanyaan yang diberikan. Karena pada strategi ini, antara siswa yang satu dengan yang lain saling bersaing dalam menjawab pertanyaan yang diberikan guru. Pada siklus I, para siswa sudah aktif dalam menjawab pertanyaan walaupun jawaban mereka belum tentu benar. Pada siklus II, keaktifan siswa dalam menjawab pertanyaan semakin meningkat, banyak siswa yang menjawab pertanyaan. 
Dari hasil wawancara dengan beberapa siswa didapat bahwa sebagian dari mereka cukup senang dengan metode co-op co-op, awalnya mereka tidak begitu faham terhadap langkah-langkah metode tersebut, namun setelah dilakukan beberapa tindakan mereka pun lebih senang karena mereka bisa menambah interaksi dengan teman-temanya dan aktivitasnya pun mulai meningkat. Pada siklus pertama aktivitas masih kurang, tapi pada siklus kedua dan kedua aktivitasnya pun mulai meningkat. Pada siklus selanjutnya, saat siswa ditanya tentang metode dan strateginya, mereka berkata kalau metode dan strateginya sudah mereka pahami bahkan langkah-langkahnya juga sudah ada yang hafal. Mereka mengatakan bahwa dengan metode dan strategi tersebut dapat meningkatkan aktivitas siswa.

Adapun dari hasil pengisian angket aktivitas siswa dapat dilihat dari rata-rata hasil pengisian angket setiap siklus. Berikut tabel aktivitas siswa pada siklus I dan II.

Tabel 2.

Hasil analisis angket aktivitas siswa pada siklus I dan II

\begin{tabular}{|c|c|c|c|c|}
\hline \multirow{2}{*}{ Indikator } & \multicolumn{2}{|c|}{ Siklus I } & \multicolumn{2}{|c|}{ Siklus II } \\
\hline & Persentase & Kualifikasi & Persentase & Kualifikasi \\
\hline Aktif dalam bertanya & 78,17 & Sedang & 85,32 & Tinggi \\
\hline Menjawab pertanyaan & 85,71 & Tinggi & 89,29 & Tinggi \\
\hline $\begin{array}{l}\text { Mengerjakan soal-soal dengan } \\
\text { diskusi }\end{array}$ & 79,17 & Sedang & 88,09 & Tinggi \\
\hline $\begin{array}{l}\text { Mampu mempresentasikan } \\
\text { hasil kerja baik individu } \\
\text { maupun kelompok }\end{array}$ & 66,07 & Sedang & 73,21 & Sedang \\
\hline $\begin{array}{l}\text { Berpartisipasi aktif dalam } \\
\text { kegiatan kelompok }\end{array}$ & 88,69 & Tinggi & 94,64 & Tinggi \\
\hline Rata-rata & 79,56 & Sedang & 86,11 & Tinggi \\
\hline
\end{tabular}

Pada siklus yang pertama angket aktivitas siswa mencapai 79,56 \% yang mempunyai kualifikasi sedang, dan pada siklus yang kedua aktivitas siswa mencapai 86,11 \% yang mempunyai kualifikasi tinggi. Hasil ini menunjukkan adanya peningkatan aktivitas siswa dari siklus I ke siklus II yaitu sebesar 6,55 \%. Dari hasil lembar observasi siswa, wawancara dengan siswa, dan hasil analisis angket, maka peneliti menyimpulkan bahwa dengan menggunakan metode Co-op co-op dan strategi peninjauan kembali dapat meningkatkan aktivitas siswa.

\section{Kreativitas siswa}

Kreativitas dalam penelitian ini difokuskan pada kemampuan untuk menghasikan banyak gagasan, kemampuan untuk mengemukakan bermacam-macam pemecahan/pendekatan terhadap masalah, kemampuan untuk menemukan sesuatu, cenderung lebih menyukai tugas yang sulit, cenderung memberi jawaban yang lebih banyak, menanggapi pertanyaan yang diajukan, mempunyai banyak pertanyaan, dan mampu menguraikan sesuatu secara terperinci. 
Kreativitas ini juga diambil dari lembar observasi kreativitas, hasil wawancara dan hasil perhitungan angket. Dari lembar observasi terlihat bahwa kreativitas siswa dari siklus I sampai siklus II juga mengalami peningkatan. Peningkatan ini terjadi ketika telah diterapkannya metode co-op co-op dan strategi peninjauan kembali. Kreativitas siswa bisa muncul pada langkah-langkah tertentu dari metode co-op co-op. Yang pertama pada langkah seleksi topik tim. Pada langkah ini guru telah membagi LKS kepada siswa kemudian mereka mengerjakan LKS tersebut. Pada siklus I, mereka belum bisa menguraikan jawaban secara terperinci, siswa masih sulit dalam mengemukakan bermacam-macam pemecahan, jawaban yang dikerjakan siswa juga masih sederhana artinya mereka kerjakan menurut rumus yang telah diajarkan, dan mereka mempunyai banyak pertanyaan tapi mereka masih takut untuk menanyakannya.

Pada siklus II, kreativitasnya semakin meningkat. Mereka mengerjakan soal yang diberikan secara terperinci atau urut sesuai langkah pengerjaannya. Dalam mengerjakan soal, mereka memberi jawaban sesuai kemampuan mereka, dan kebanyakan dari mereka mempunyai banyak pertanyaan yang akan ditanyakan. Langkah selanjutnya yang muncul kreativitas yaitu saat presentasi. Pada siklus I, saat temannya presentasi masih banyak siswa yang memilih diam daripada bertanya. Dalam menghasilkan gagasan, mereka masih kurang dan hanya sebagian siswa yang mau menjawab ketika guru bertanya. Pada siklus II, mereka banyak yang bertanya terhadap hal yang tidak mereka fahami. Hanya sebagian siswa yang dapat menghasilkan gagasan. Dan sebagian besar sudah mampu menanggapi apa yang ditanyakan guru.

Setelah metode co-op co-op, guru menerapkan strategi peninjauan kembali. Pada siklus I, kebanyakan dari mereka tidak senang ketika mereka diberi soal yang sulit, mereka lebih senang soal yang mudah. Pada saat menjawab soal, sebagian dari mereka masih mengerjakan dengan cara yang diberikan guru sehingga jawaban mereka agak lama. Pada siklus II, sebagian dari mereka senang ketika guru memberikan soal yang sulit. Dalam menjawab soal, mereka kerjakan dengan cara mereka sendiri artinya mereka menemukan jawaban dengan cepat kemudian mereka langsung menjawabnya. Dan pada siklus yang kedua, strategi ini belum bisa diterapkan karena waktunya telah selesai. Dari siklus I dan II dapat dilihat bahwa kreativitas pada strategi peninjauan kembali semakin meningkat.

Dari hasil wawancara dengan beberapa siswa didapat bahwa dengan metode co-op co-op dan strategi peninjauan kembali dapat meningkatkan kreativitasnya. Mereka mengatakan bahwa dengan mengerjakan soal yang ada dalam LKS mereka bisa mengerjakannya dengan sekreatif mungkin. Hal ini dibuktikan dengan banyaknya pertanyaan yang muncul saat mereka mengerjakan LKS, sebagian siswa yang diwawancarai mereka mengatakan bahwa mereka kurang suka jika di beri tugas yang sulit. Hal ini terjadi pada siklus I. Pada siklus II, mereka mengatakan bahwa kalau mereka sudah mampu untuk mengemukakan gagasan, pertanyaan dan bermacam-macam pemecahan, dan mereka juga sering menanggapi pertanyaan yang diajukan baik saat temanya bertanya maupun guru yang mengatakan. Mereka mengatakan bahwa dengan metode dan strategi tersebut dapat meningkatkan kreativitas siswa. 
Adapun dari hasil pengisian angket kreativitas siswa dapat dilihat dari rata-rata hasil pengisian angket setiap siklus. Berikut analisis perhitungannya pada siklus I, dan II.

Tabel 3.

Hasil analisis angket kreativitas siswa pada siklus I \& II

\begin{tabular}{|c|c|c|c|c|}
\hline \multirow{2}{*}{ Indikator } & \multicolumn{2}{|c|}{ Siklus I } & \multicolumn{2}{|c|}{ Siklus II } \\
\hline & Prosentase & Kualifikasi & Prosentase & Kualifikasi \\
\hline $\begin{array}{l}\text { Kemampuan untuk } \\
\text { menghasilkan gagasan }\end{array}$ & 51,59 & kurang & 59,13 & Kurang \\
\hline $\begin{array}{l}\text { Kemampuan untuk } \\
\text { mengemukakan barmacam- } \\
\text { macam } \\
\text { pemecahan/pendekatan } \\
\text { terhadap masalah. }\end{array}$ & 50 & Kurang & 60,12 & Sedang \\
\hline $\begin{array}{ll}\text { Kemampuan } & \text { untuk } \\
\text { menemukan sesuatu. } & \end{array}$ & 60,12 & Sedang & 69,05 & Sedang \\
\hline $\begin{array}{l}\text { Cenderung lebih menyukai } \\
\text { tugas yang sulit. }\end{array}$ & 61,90 & Sedang & 62,50 & Sedang \\
\hline $\begin{array}{l}\text { Cenderung memberi jawaban } \\
\text { yang lebih banyak. }\end{array}$ & 46,43 & Kurang & 54,76 & Kurang \\
\hline $\begin{array}{l}\text { Menanggapi pertanyaan yang } \\
\text { diajukan. }\end{array}$ & 68,45 & Sedang & 75 & Sedang \\
\hline $\begin{array}{l}\text { Mempunyai banyak } \\
\text { pertanyaan. }\end{array}$ & 63,09 & Sedang & 69,64 & Sedang \\
\hline $\begin{array}{l}\text { Mampu menguraikan sesuatu } \\
\text { secara terperinci. }\end{array}$ & 76,19 & Sedang & 79,76 & Sedang \\
\hline Rata-rata & 59,72 & Kurang & 66,25 & Sedang \\
\hline
\end{tabular}

Pada siklus yang pertama angket kreativitas siswa mencapai 59,72 \% yang mempunyai kualifikasi kurang, pada siklus yang kedua kreativitas siswa mencapai 66,25 $\%$ yang mempunyai kualifikasi sedang. Hasil ini menunjukkan adanya peningkatan kreativitas siswa dari siklus I ke siklus II yaitu sebesar 6,53 \%. Dari sini, maka peneliti menyimpulkan bahwa dengan menggunakan metode Co-op co-op dan strategi peninjauan kembali dapat meningkatkan kreativitas siswa.

Berdasarkan data-data yang telah dideskripsikan di atas, maka peneliti menyimpulkan bahwa dari semua hasil yang diperoleh tersebut dapat menjawab permasalahan yang diajukan dalam penelitian yaitu dengan menggunakan metode Co-op co-op dan strategi peninjauan kembali dapat meningkatkan kreativitas siswa.

\section{KESIMPULAN DAN SARAN}

Penelitian ini menyimpulkan bahwa penerapan metode Co-op Co-op dan strategi peninjauan kembali pada pembelajaran matematika kelas VIII SMP Sunan Averroes Yogyakarta dapat meningkatkan aktivitas siswa. Dari hasil angket dapat diketahui bahwa 
terdapat adanya peningkatan aktivitas siswa dari siklus I ke siklus II yaitu sebesar 6,55 \%. Peningkatan aktivitas siswa terlihat pada saat siswa di beri LKS. Pada saat mengerjakan, mereka masih malu untuk bertanya kepada temannya tetapi mereka langsung bertanya kepada guru atau peneliti, tapi setelah dilakukan beberapa tindakan, mereka bertanya kepada temannya dan apabila temannya tidak bisa mereka bertanya kepada guru. Pada saat dilakukan tindakan yang pertama, mereka mengerjakan soal dengan sendiri-sendiri tetapi kemudian mereka kerjakan dengan diskusi dengan teman-temannya. Masing-masing siswa berpartisipasi aktif dengan kelompoknya dalam menyelesaikan soal yang diberikan. Pada saat presentasi baik individu maupun kelompok, pada siklus I siswa masih malu-malu bahkan ada yang tidak mau presentasi, tetapi pada siklus selanjutnya mereka sudah berani untuk mempresentasikan hasil pekerjaannya. Saat diterapkannya strategi peninjauan kembali, guru memberikan pertanyaan kepada siswa dan siswa pun mampu untuk menjawabnya, mereka saling bersaing dalam menjawab pertanyaan yang diberikan.

Penelitian ini menyimpulkan bahwa penerapan metode Co-op Co-op dan strategi peninjauan kembali pada pembelajaran matematika kelas VIII SMP Sunan Averroes Yogyakarta dapat meningkatkan kreativitas siswa. Dari hasil angket diketahui bahwa peningkatan kreativitas siswa dari siklus I ke siklus II yaitu sebesar 6,53 \%. Pada saat diskusi, awalnya siswa belum bisa menghasilkan banyak gagasan, hanya sebagian kecil yang mampu, tapi setelah dilakukan beberapa tindakan lebih banyak siswa sudah mampu menghasilkan gagasan. Pada saat pembentukan tim, tim dibagi menjadi 4 kelompok yang terdiri dari siswa yang heterogen hal ini menjadikan mereka dapat bertukar pikiran dengan temannya dan melakukan tanya jawab dengan teman sekelompoknya. Pada awal mengerjakan LKS, mereka mengerjakannya dengan rumus yang ada tapi setelah mengerjakan beberapa LKS, lebih banyak siswa sudah mampu untuk mengerjakan dengan cara mereka sendiri yang juga masih mengikuti rumus yang ada. Dalam mengerjakan soal, mereka kerjakan dengan terperinci atau urut sesuai urutan pengerjaan yang ada dan mereka kerjakan dengan cara yang lebih kreatif. Setelah mengerjakan LKS mereka presentasi, yaitu presentasi individu kepada kelompoknya, dari sini terlihat kreativitasnya, yaitu dalam menanggapi pertanyaan yang diajukan oleh teman sekelompoknya. Langkah selanjutnya yaitu persiapan presentasi tim. Kemudian dilakukan presentasi yang kedua yaitu presentasi tim/kelompok, awalnya mereka masih malu untuk bertanya, mereka memilih diam daripada bertanya walaupun mereka tidak bisa, namun setelah dilakukan beberapa siklus, mereka pun berani bertanya saat temannya presentasi dan apabila presentator tidak bisa menjawabnya, maka guru yang akan menjawabnya.

\section{DAFTAR RUJUKAN}

Amin, Moh. (1980). Peranan Kreativitas dalam Pendidikan, Majalah Analisis. Jakarta: Depdikbud.

Depdikbud. (1998). Kamus Besar Bahasa Indonesia. Jakarta: Balai Pustaka.

Fattah, Nanang. (2004). Landasan Manajemen Pendidikan. Bandung : PT Remaja Rosdakarya. 
Hargenhahn B.R., \& Olson M.H. (2008). Theories of learning. (Terjemahan Tri Wibowo BS.). Upper Saddle River, NJ: Pearson Education. (Buku asli diterbitkan tahun 2008)

McGregor, Debra. (2007). Developing thinking developing learning, a guide to thinking skills in education. USA : The McGraw-Hill Companies

Munandar, Utami. (2004). Pengembangan Kreativitas Anak Berbakat. Jakarta: PT Rineka Cipta.

Nitko, A.J., \& Brookhart, S.M. (2007). Educational assessment of students. Columbus, $\mathrm{OH}$ : Merill.

Race, Phil. (2010). Making learning happen. London: Sage Publications Ltd.

Salim, Peter dan Yenny Salim. (1991). Kamus Bahasa Indonesia Kontemporer. Jakarta: Modern English Press.

Slavin, R. E.. (2006). Educational psychology: Theory and practice ( $8^{\text {th }}$ ed.). Boston: Pearson Education, Inc.

Sugiyono. (2007). Metode Penelitian Pendidikan Pendekatan Kuantitatif, Kualitatif, dan $R \& D$. Bandung: Alfabeta.

Sutrisno. (2005). Revolusi Pendidikan di Indonesia. Yogyakarta: Ar Ruzz.

Syah, Muhibbin. (2006). Psikologi Pendidikan dengan Pendekatan Baru. Bandung: PT Remaja Rosdakarya.

Winkel, W.S. (2004). Psikologi Pengajaran. Yogyakarta: Media Abadi. 